\title{
Efficacy of Citizens' Participation in Strategic Planning towards Adaptation to Climate Risk: Evidence from Densely Populated Emerging Urban Centres
}

\author{
Vincent A. Onodugo', Ugonna C. Nkwunonwo ${ }^{2 *}$, Obinna J. Ubani ${ }^{3}$ \\ ${ }^{1}$ Department of Management, University of Nigeria Enugu Campus, Enugu, Nigeria \\ ${ }^{2}$ Department of Geoinformatics and Surveying, University of Nigeria Enugu Campus, Enugu, Nigeria \\ ${ }^{3}$ Department of Urban and Regional Panning, University of Nigeria Enugu Campus, Enugu, Nigeria \\ Email: *ugonna.nkwunonwo@unn.edu.ng
}

How to cite this paper: Onodugo, V. A., Nkwunonwo, U. C., \& Ubani, O. J. (2020). Efficacy of Citizens' Participation in Strategic Planning towards Adaptation to Climate Risk: Evidence from Densely Populated Emerging Urban Centres. Journal of Service Science and Management, 13, 745767.

https://doi.org/10.4236/jssm.2020.135047

Received: September 12, 2020

Accepted: October 23, 2020

Published: October 26, 2020

Copyright $\odot 2020$ by author(s) and Scientific Research Publishing Inc. This work is licensed under the Creative Commons Attribution International License (CC BY 4.0).

http://creativecommons.org/licenses/by/4.0/

\begin{abstract}
Poor electricity supply is a dismal feature of densely populated cities. Within especially developing countries (DCs), this situation prompts consideration for human intervention, such as the use of candles, lanterns and stand-by generators, all of which are major drivers of climate change by the emission of CO (Carbon II Oxide) into the atmosphere. Evidently, the adverse climatic effects such as flooding, hurricane and urban heat-have set-forth extant academic debates. Still, adaptation in densely populated cities within the DCs is surrounded by many uncertainties. This study answers the most fundamental question which is: how are people living in densely populated cities able to adapt to the climate risk induced by using alternative electricity sources? Grounded on the theory of resource-based view (RBV), the study integrates strategic planning techniques into climate risk adaptation, through a survey conducted around three most populated locations in Enugu metropolis of Nigeria. The results indicate a good knowledge of climate change within the area, although the level of public participation in urban development efforts and climate change adaptation remained poor. We argue that much improvement in awareness and compliance to climate risk adaptation will occur in the DCs if more people are involved in the strategic policy and planning process. This study thus reinforces the existence of climate risk in the area, enables increased public participation in policy formulation, simplifies the present complex process in the delivery of urban development goals, and supports achieving the goal of building a society resilient to climate risk.
\end{abstract}




\section{Keywords}

Climate Risk, Densely Populated Urban Centres, Strategic Planning, Resource-Based View, Resilience, Urban Development

\section{Introduction}

Access to reliable electricity and other urban services is fundamental to the efficient functioning of urban centers. Generally, a city-wide electricity distribution is underpinned by the main grids to ensure greater output uniformity, quality control, and maintenance (Shafiullah et al., 2013; Kunaifi \& Reinders, 2018). However, due to poor management, sporadic catastrophes, obsolescence, and notorious vandalisation of energy infrastructure, the main grids are usually affected, leading to temporary or total interruption of electricity supply. Although this situation is common in many places, it seems more pronounced in poor localities where the response to infrastructural mal-function is often not immediate, and blackouts may linger to longer periods, causing widespread hysteria, frustration and economic disruptions (Pineau, 2008). In 2015, this situation warranted the International Energy Agency (IEA) to study the global energy access, and its results showed around 1.2 billion people, who represent about $16 \%$ of the global population, were without access to reliable electricity supply (International Energy Agency, IEA, 2016). In fact, lack of access to reliable electricity now drives many urban residents in especially poor localities to source for immediate alternatives which constitute major concerns for global climate change (Bazilian et al., 2011; Nkwunonwo \& Mafimisebi, 2013; Jakob et al., 2015).

Climate change, which refers to variations in the statistical distribution of the average weather pattern, is undergirded by the inevitable geophysical processes, which underpin the universe. Biotic processes, tectonic motions, volcanic eruption and solar radiation are key primordial factors in the emergence of climate change (Crowley, 2000). However, the impacts of human activities, since the Industrial Revolution, have substantially escalated climate change to a major global phenomenon and a real problem for societies (Arrow, 2007; Kaufmann et al., 2011). High earth's surface temperature, increased frequency and intensity of rainfall events, melting of glaciers, and rising sea levels are now crucial issues, as they are inevitably associated with hazardous events such as wildfires, flooding, heat waves, earthquakes, erosion, landslide and drought (McMichael et al., 2006; Lenderink \& Van Meijgaard, 2008; Hirabayashi et al., 2013). The human, economic, and ecological impacts of these events considered across spatial and temporal scales, especially within urban centers, are significant at the same time as they have spurred important debates within human development, earth sciences and environmental management research (Hunt \& Watkiss, 2011; Adger et al., 2013; Nkwunonwo, 2015; Nkwunonwo et al., 2016a). Astonishingly, recent stu- 
dies based on global climate models such as those of Moss et al. (2010), Mote \& Salathe (2010), and Lutz \& Muttarak (2017) have predicted and supported the views that the occurrences of these events are likely to increase in the future. Thus, how to make society adapt to the inexorable realities of the risks associated with climate change through robust risk mitigation measures is now a major theme of rising interest in climate change research (for example: Adger, 2010; Jones et al., 2012; Gillard et al., 2016; Tàbara et al., 2019).

Adaptation measures to mitigate the vulnerabilities of communities to climate risks are crucial and have been discussed extensively in sustainability sciences and human ecology research (for examples, Smit \& Wandel, 2006; Reenberg et al., 2008; Kates et al., 2012). Adaptation generally is an ongoing evolutionary or lifelong) process by which a system (referring to elements at risk) adjusts fairly to threats within its environment. Thus, a system is adaptive to climate risk if it is able to maximise the potentials of climate change within its environment rather than being vulnerable to them. Such a process is essential for impact and vulnerability assessment as well as the development of climate risk mitigation policies (Smit \& Pilifosova, 2003; Hoffmann \& Sgrò, 2011). Climate risk adaptation experts contemplate ways to integrate various techniques and models in other to reach the goal of informed risk management decision (Bowyer et al., 2014). The International Panel on Climate Change (IPCC) proposed a strategy by which risk assessment of climate change events could support public awareness and capacity development as well as institutional robustness towards investment priorities for climate risk adaptation (Intergovernmental Panel on Climate Change, IPCC, 2014). From a realistic risk management perspective, this IPCC strategy largely depends on identifying and analysing the major components of risk, namely, the likelihood of occurrence of a climate change events, exposure of elements at risk and their vulnerabilities. In urban centers, this will require proper urban governance and management, wider awareness and knowledge of climate change among the general public, public participation in urban development and risk adaptation policy formulation, along with appropriate techniques to model large scale topographic and human related features using quality datasets. However, these requirements are of crucial research concern within the context of densely populated urban centers in developing countries (DCs) such as Enugu, Nigeria. This is in addition to poor political will which constitutes major challenges to financing climate risk adaptation on the basis of IPCC strategy (Schipper \& Pelling, 2006; Intergovernmental Panel on Climate Change, IPCC, 2014).

Climate risks adaptation within the context of densely populated urban centers, especially in developing societies, is a major research discussion. Some of the studies that have considered this important issue were critical of the level of societal preparedness for adaptation, which is largely generic despite the realism and the distinctive characteristic nature of climate risk (McLeman, 2010; Henstra, 2012; Runhaar et al., 2012; Marfai et al., 2015; Araos et al., 2016). There is a lack of a real, evidence-based climate risk adaptation policy in the DCs. It ap- 
peared societies are unable to integrate perspectives from coastal engineering, economics, finance, and social sciences to adapt to the real dynamics of climate change (Hinkel et al., 2018). Policy making and planning by governments of the DCs is often based on a top-down approach which increases the chain of activities as well as uncertainties towards meeting the challenges of climate risk (Burch et al., 2010; Conway \& Mustelin, 2014). This is a major gap that this study intends to fill by using evidence to support that involving the public in strategic planning and policy making will aid adaptation and mitigation measures towards climate change. These issues raise some crucial questions which highlight the importance of the present research. Firstly, how can climate risk adaptation be achieved despite the lack of necessary prerequisites which are acknowledged globally? Secondly, what empirical evidence underscores the level of awareness of climate change within the context the DCs? Although a good number of studies have shown the limited knowledge of climate risk in the DCs, the available evidence is imprecise, often at regional scales and mostly based on limited data samples (Vedeld et al., 2016). Moreover, the uncertainties in these evidences have not been eased of the translational complexities in climate risk. Thirdly, what strategy can be adopted or created solely for the purpose of utilising the currently available datasets to evolve climate risk adaptation? This issue has not been adequately attempted by research in the context of the DCs, and therefore addressing it in the present research is a major novelty and research contribution to the knowledge of climate risk. Whereas many studies have applied currently available datasets, the problem of uncertainty in the result of analysis has not been addressed. Finally, given that the need to reinforce institutional capacity in the DCs raises a crucial research question, it should be the focus of any research to investigate possible strategies needed to increase the efficiency of presently applicable adaptation measures?

The present research provides possible answers to these issues. A new framework of strategic planning is developed and applied to Enugu metropolis of $\mathrm{Ni}$ geria. The new framework will employ a semi-structured questionnaire, collected over a sample of 1000 respondents and analysed to investigate how increased public participation can affect the formulation and enforcement of urban development policies. It will also investigate how the already complex model of adaptation to climate risk in Enugu can be simplified.

\section{Brief Review of the Literature on Strategic Planning}

Strategic planning dates to the origin of management science, which can be traced to operations research (Hillier \& Price, 2004). Conceptually, strategic planning is a management procedure to define the main objectives of a task, and to develop practical ways of achieving it within the limits of available resources (Boyd \& Reuning-Elliott, 1998; Bryson, 2011). In strategic planning, the idea is to ensure that all stake holders involved in a task are working toward a common goal to enhance the performance of a system and to encourage community participation. This is particularly important in climate risk adaptation, where the 
participation of a community is essential in developing a suitable culture or measure to adapt to climate risk. Strategic planning has been extensively discussed within management research, with some important evidence of growing sophistication (Miller \& Cardinal, 1994; Grant, 2003; Poister \& Streib, 2005). Critical issues arising from recent discussions show that strategic planning is a culture, which every human endeavour, rather than just business organisations, should develop for effective performance, increased profit and sustainability of organisations (Aram \& Cowen, 1990; Poister, 2010; Broman \& Robèrt, 2017; Missimer et al., 2017). Although the majority of these discussions relate essentially to leadership, business, and finance, there are few studies, however, which underpin the tenable position of strategic planning in the context of urban management and climate risk adaptation.

Tanskanen (2000) used strategic planning for the management of municipal solid waste in the Helsinki Metropolitan area of Finland. The study applied a computer model to find and analyse separation strategies fulfilling the recovery rate targets adopted for municipal solid waste in Finland, i.e., $50 \mathrm{wt} \%$ by the end of 2000 and $70 \mathrm{wt} \%$ by 2005 . With empirical evidence, the result of the study highlights the significant prospects of strategic planning for municipal solid waste management. Among other benefits, the strategy made it possible to determine the effects of separation strategies on the costs and emissions caused by the whole municipal solid waste. Tohidi et al. (2010) used a balanced scorecard (BSC), which is one of the performance measurement tools more frequently used in strategic planning to determine the intangible assets of the educational organization of Iran. The authors show how a strategy map is planned for educational organizations and how necessary data are gathered with interviews held with managers who had planned strategies for their organizations and who had not, by using BSC tool. This system proves to be a suitable alternative for the traditional management approaches in Iranian educational systems. Hallegatte (2009) examined various climate change adaptation strategies and acknowledged the possibilities of both desirable and undesirable effects, which may impact on the adaptation means of other features not within the area of interest. Therefore, the study promotes mainly integrated design and assessment of adaptation policies, which can be developed through community participation and strategic planning. Mukheibir \& Ziervogel (2007) present an overarching framework that would facilitate the development of a Municipal Adaptation Plan (MAP) in the city of Cape Town. This framework simplifies planning for climate risk adaptation at the municipal level, thus enabling a risk manager to uncover climate risk threats and resource mobilization issues at small levels of human settlements.

Despite the obvious possibilities of strategic planning for climate risk adaptation, scaling up the level of public participation is crucial, and might increase the needed logistics and therefore the level of uncertainty. For the densely populated areas with high demographic distribution, which is symptomatic of climate risk adaptation within the context of Enugu, Nigeria, strategic planning is a work in progress. Whilst this situation is more disturbing with the predictions of wor- 
sened future climate change challenges in many urban centers globally, it highlights the relevance of considering a strategic planning in the present research. It also highlights the importance of a local, place-based planning, although there are important barriers and challenges which were investigated in Measham et al. (2011). These include leadership, institutional framework and conflicting planning agendas, now constitute major research issues. The present research considers these challenges and focuses on how to address them with goal to develop a tenable climate risk adaptation strategy for the densely populated urban centre within Enugu Nigeria. For the present research, how a simple model that uses the elements of vision, mission, objectives, strategy and action plans (VMOSA) can be formulated and used to develop a climate change adaptation measure for the Enugu urban has been addressed.

\section{Theoretical Framework: The Resource-Based View Theory}

The literature on strategic management is replete with theories that attempt to explain the behaviour of organizations and their ability to utilize available resources in pursuit of their mission. One of the principal theories that has ruled the strategic planning and management thinking for quite some time is the Resource Based View (RBV) Theory. RVB succeeded and for the most part, complemented the Industrial Organization View (IOV). With Porter $(1996,2001)$ and Bain (1968) as its major proponents, IOV hinges the success and competitive strength of the organization on certain exogenous industrial factors. Owners of the organization within this IOV or Porterian paradigm spent their time looking for competitive strengths outside the organization, mainly in the working dynamics of the industry forces. RBV arose to complement the IOV by identifying other critical endogenous resources that will help organizations to achieve its key outcomes.

Penrose (1959) was the first researcher to propose a resource-based view, even though the study's analysis of the resources was aimed at understanding the output of the firm rather than the intricate processes and behaviour leading to that outcome. Overtime interest in this approach grew, mostly as an alternative to the industrial organization model. The more recent proponents of RVB were Wernerfelt (1984) and Barney (1991, 2002). The essential proposition of RVB is that for an organization to attain sustained competitive advantage (SCA), it must procure and control certain rare, valuable, and inimitable resources and have the organizational capacity to utilize these resources (Kraaijenbrink et al., 2010). The inherent value addition of RVB is that it hinges the success of organizational outcomes on both internal and internal factors unlike IOV that mostly relied on external industrial factors for success. Consequently, some scholars posit that RVB is complementary, not a replacement of IOV (Peteraf \& Barney, 2003; Mahoney \& Pandian, 1992).

One key distinguishing feature of this theory is its unique distinction between resources and competencies (Grant, 1991; Amit \& Schoemaker, 2003). The differences are captured thus:

1) The resources are the input of the productive process, the basic unit of the 
analysis, which needs accumulation and co-ordination. According to Grant (1991), six categories of resources exist: financial; physical (plant capacity, availability of raw materials, etc.); human; technological (number and importance of patents, etc.); reputation (recognition of the brand, customer fidelity, etc); and organizational (values, management styles, etc).

2) Competencies are placed at a higher level of the aggregation, and identify the capacity of a group of resources, if properly managed, to carry out an activity or reach a target (Aaker, 2009). The competencies explain how two firms, though with similar objectives and the same resources, can achieve different performances, or vice versa, how two firms can obtain similar performances even if with different resources.

Originally, RVB, like most other strategic planning models, were designed for profit making organisations in a competitive market environment. Its theoretical appeal, however, is applicable to other realms. The basic tenet of RBV is that organisational success is critical to possessing key requisite resources that it needs, and its capacity to utilise these resources effectively. Climate change and efforts to evolve an adaptation mechanism have become an issue of global concern. To effectively design functional, cost effective, and easily usable climate change adaptive mechanism, government and non-governmental agencies must engage, involve, and interact with a critical mass of people resources for it to work and be effectively used. Peoples' inputs are required during policy formulation and more importantly during implementation. According to this theory, success in climate change adaptation mechanisms can be achieved if and when the driving organisations possess the capacity to engage, involve, and utilise the critical resources of people in the process of strategic planning design and implantation.

\section{Brief Description of the Study Area}

The study on climate risk adaptation in densely populated urban areas was carried out by Abakpa-Nike, Obiagu, and Coal-camp urban centres in Enugu metropolis of Nigeria (Figure 1). Enugu with a current estimated population of 688,000 according to World Bank projections (World Bank, 2019) is the second-largest city, after Aba, in the south-eastern geopolitical zone of Nigeria by demographic profile. The socio-economic variables of the three surveyed urban centres indicated that majority of the respondents were within the age range of 18 - 55 years, $12.5 \%$ were 18 - 25 years of age, $20.4 \%$ were 26 - 35 years, $16.3 \%$ were 36 - 45 years while $50.8 \%$ were above 46 - 55 years of age (Table 1 ). This means that the research had the fortune of those with experience marked by age. Ten percent $(10.4 \%)$ of the respondents had no formal education, while $89.65 \%$ attained one level of education or the other. $3.8 \%$ below primary education, $8.6 \%$ secondary education, only, $12 \%$ attained diploma level, $57 \%$ were first degree holders, $5.8 \%$ and $2.4 \%$ held second degrees and above second degrees respectively). This shows that education is somewhat a key prospect for the Enugu city residents, but also an advantage for the present research. 


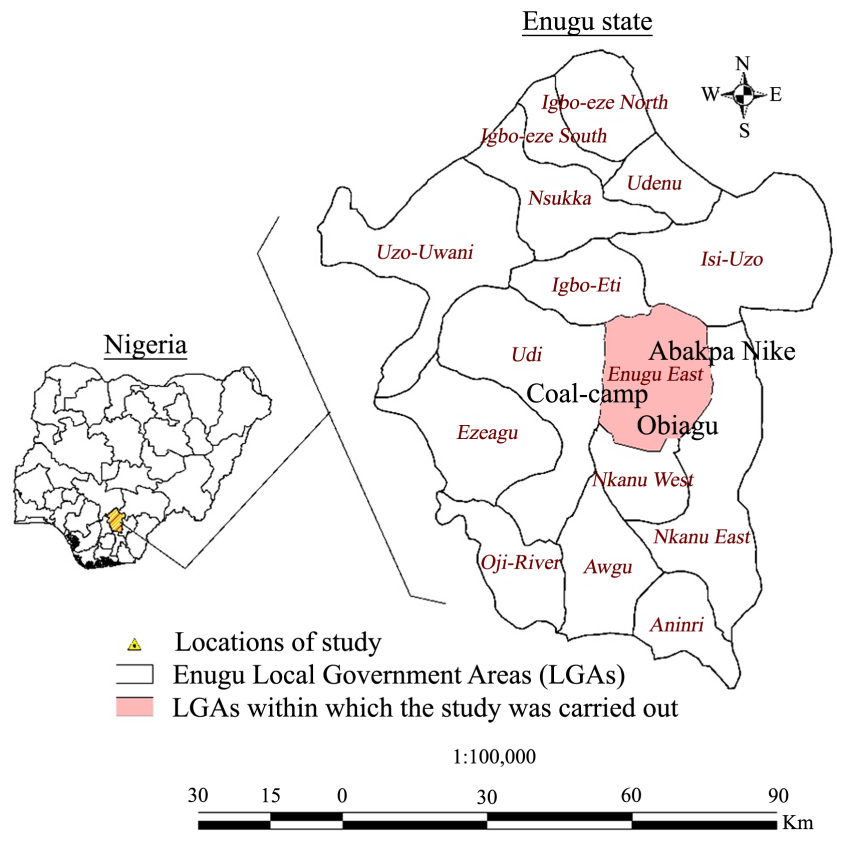

Figure 1. Study area: the locations of Abakpa, Coal camp and Obiagu, where the research data were collected, within the political jurisdiction of Enugu state. Inset map delineates the location of Enugu state within the geographical context of Nigeria.

Table 1. Respondents' length of stay in the study areas.

\begin{tabular}{|c|c|c|c|c|}
\hline \multirow{2}{*}{ S/No. } & \multirow{2}{*}{ Variables } & \multirow{2}{*}{ Factors } & \multicolumn{2}{|c|}{ Responses } \\
\hline & & & Frequency & $\%$ \\
\hline \multirow{5}{*}{1.} & \multirow{5}{*}{ Length of stay in the area } & Below 2 years & 24 & 13.3 \\
\hline & & $2-5$ years & 59 & 32.8 \\
\hline & & $6-10$ years & 8 & 4.4 \\
\hline & & $11-15$ years & 22 & 12.2 \\
\hline & & Above 15 years & 67 & 37.2 \\
\hline \multirow{5}{*}{2.} & \multirow{5}{*}{ Ages of the respondents } & Below 18 years & 0 & 0 \\
\hline & & $18-25$ years & 23 & 12.5 \\
\hline & & $26-35$ years & 37 & 20.4 \\
\hline & & $36-45$ years & 29 & 16.3 \\
\hline & & $46-55$ years & 91 & 50.8 \\
\hline \multirow{8}{*}{3.} & \multirow{8}{*}{ Educational attainment } & Formal education & 161 & 89.6 \\
\hline & & No formal education & 19 & 10.4 \\
\hline & & Below primary education & 7 & 3.8 \\
\hline & & Only secondary education & 15 & 8.6 \\
\hline & & Diploma & 22 & 12 \\
\hline & & First degree & 103 & 57 \\
\hline & & Second degree & 10 & 5.8 \\
\hline & & Above second degree & 4 & 2.4 \\
\hline
\end{tabular}


Enugu houses three important tertiary educational institutions in NigeriaUniversity of Nigeria, Enugu Campus (UNEC), Enugu state university of science and technology (ESUT), and Institute of Management and Technology (IMT). This also reinforces the educational profile of the city While many of the respondents were either civil servants or regular and occasional school workers. The 82-division military cantonment (Army barracks) is also located in Enugu and the three major hospitals (University of Nigerian Teaching Hospital, Ituku-Ozalla, ESUT teaching hospital Park lane, and National Orthopaedic Hospital) all of which give the city a characteristic geographical importance within the Nigerian context. The study locations are the fastest growing in Enugu, furnished with connectivity and various road networks, although electricity supply remained the major impasse. The major occupation of the respondents was civil servants (42.5\%), the majority (50\%) of which were from Abakpa compared to Obiagu (35\%). One quarter (25\% of the respondents) of the total population studied was combining civil service and many other occupations.

\section{Method and Data}

To assess the climate change profile and the current level of adaptation in the densely populated area of Enugu, residents of Enugu metropolis were surveyed in July 2018. In total, one hundred and eighty working age residents between 18 and 55 years from three densely populated locations: Cole-camp, Obiagu, and Abakpa-Nike (sixty for each location) were sampled using a semi-structured questionnaire. These locations were chosen because they are the fastest growing localities in Enugu, adjudged by the current demographic records and the rate of growth of localities in Enugu (World Bank, 2019).

The semi-structured questionnaire instrument was designed in English and aimed to evaluate the key components of climate change and strategic management towards climate risk adaptation. Participants were expected to provide responses to enable the researchers ascertain mainly the reality of climate risk in the study area, climate impacts of alternatives electricity resources, the level of awareness or current knowledge of climate change and the community's participation in the overall decision making for urban development and adaptation policies that may be necessary to contemplate in the research. The survey instrument contained questions such as: were you consulted in siting some urban infrastructure in your area? How can you describe the electricity supply in your area? What alternative source of electricity is available in your area? Are you aware of climate change and the associated risks thereof? Does the government or its agents involve the residents in deliberating on the risk associated with climate change in your area? What are the ways in which people in your area have adapted to climate change events such as flooding, urban heat, high intensity, and high frequency rainfall? Suggest possible ways in which the government and your local community can partner to formulate a climate risk adaptation measure suitable to your area.

Three data collection assistants were recruited for this research. Each assistant was to cover one of the case studies for periods, during which questionnaires 
were administered to participants drawn randomly from streets, main parks and garages, market places, and eateries. The randomization of data collection for this research was accomplished by sampling one in every ten persons, although the willingness of the respondents was also factored in. Each participant was given enough time to complete the questionnaires and in situation where there arose ambiguities with any of the questions, the field assistants were expected to throw in some explanations. Participants were assured of their anonymity and encouraged to provide as much as possible candid and well-informed responses. Summaries of the data collected and analysed are presented in Tables 1-8.

Table 2. Awareness of climate change and its components in the study area.

\begin{tabular}{|c|c|c|c|c|}
\hline \multirow{2}{*}{ S/No. } & \multirow{2}{*}{ Variables } & \multirow{2}{*}{ Factors } & \multicolumn{2}{|c|}{ Responses } \\
\hline & & & Frequency & $\%$ \\
\hline \multirow{2}{*}{1.} & \multirow{2}{*}{$\begin{array}{l}\text { Awareness of climate change } \\
\text { and associated risks }\end{array}$} & Aware of Climate change & 143 & 79.4 \\
\hline & & Not aware of climate change & 33 & 18.3 \\
\hline \multirow{4}{*}{2.} & \multirow{4}{*}{$\begin{array}{l}\text { Awareness of the changes } \\
\text { in the climate components }\end{array}$} & Rainfall & 114 & 63.3 \\
\hline & & Flooding & 70 & 38.9 \\
\hline & & Sun intensity & 89 & 49.4 \\
\hline & & River overflow & 32 & 17.8 \\
\hline \multirow{6}{*}{3.} & \multirow{6}{*}{$\begin{array}{l}\text { Source of climate } \\
\text { change knowledge }\end{array}$} & Radio & 74 & 47.7 \\
\hline & & Newspaper & 47 & 30.3 \\
\hline & & Internet & 4 & 2.6 \\
\hline & & Public gathering (Church) & 26 & 16.8 \\
\hline & & Personal study & 4 & 2.6 \\
\hline & & Television & 25 & 13.9 \\
\hline
\end{tabular}

Table 3. Alternative electricity sources and risk in the study area.

\begin{tabular}{|c|c|c|c|c|}
\hline \multirow{2}{*}{ S/No. } & \multirow{2}{*}{ Variables } & \multirow{2}{*}{ Factors } & \multicolumn{2}{|c|}{ Responses } \\
\hline & & & Frequency & $\%$ \\
\hline \multirow{5}{*}{1.} & \multirow{5}{*}{ Status of electricity supply } & Steady & 4 & 2.2 \\
\hline & & Moderately steady & 14 & 7.8 \\
\hline & & Poor & 108 & 60 \\
\hline & & Irregular & 50 & 27.8 \\
\hline & & No electricity & 4 & 2.2 \\
\hline \multirow{4}{*}{2.} & \multirow{4}{*}{ Alternatives sources of electricity } & Generator & 146 & 81.1 \\
\hline & & Lantern & 24 & 13.3 \\
\hline & & Candle & 10 & 5.6 \\
\hline & & Inverter & 0 & 0 \\
\hline \multirow{5}{*}{3.} & \multirow{5}{*}{$\begin{array}{l}\text { Risk in the most prevalent } \\
\text { alternative source of electricity }\end{array}$} & Fire outbreak & 68 & 37.8 \\
\hline & & Air pollution & 40 & 22.2 \\
\hline & & Depletion of ozone layer & & \\
\hline & & Noise pollution & 45 & 25 \\
\hline & & All of the above & 27 & 15 \\
\hline
\end{tabular}


Table 4. The level of community participation and effects on climate risk adaptation.

\begin{tabular}{|c|c|c|c|c|}
\hline \multirow{2}{*}{ S/No. } & \multirow{2}{*}{ Variables } & \multirow{2}{*}{ Factors } & \multicolumn{2}{|c|}{ Responses } \\
\hline & & & Frequency & $\%$ \\
\hline \multirow{2}{*}{1.} & \multirow{2}{*}{$\begin{array}{l}\text { Community participation } \\
\text { in urban development }\end{array}$} & Consulted & 32 & 17.8 \\
\hline & & Not consulted & 148 & 82.2 \\
\hline \multirow{4}{*}{2.} & \multirow{4}{*}{$\begin{array}{l}\text { Potential of community } \\
\text { input in development }\end{array}$} & Very high & 142 & 78.9 \\
\hline & & Moderate & 38 & 21.1 \\
\hline & & Small input & & \\
\hline & & No input & & \\
\hline \multirow{2}{*}{3.} & \multirow{2}{*}{$\begin{array}{l}\text { Community enlightenment } \\
\text { on climate change }\end{array}$} & Yes & 68 & 37.8 \\
\hline & & No & 112 & 62.2 \\
\hline \multirow{5}{*}{4.} & \multirow{5}{*}{$\begin{array}{l}\text { Effectiveness of community } \\
\text { enlightenment on climate change }\end{array}$} & Very high & 24 & 33.3 \\
\hline & & High & 8 & 11.1 \\
\hline & & Moderate & 10 & 13.9 \\
\hline & & Little & 8 & 4.4 \\
\hline & & None & 22 & 30.6 \\
\hline \multirow{2}{*}{5.} & \multirow{2}{*}{$\begin{array}{l}\text { Community involvement in decision } \\
\text { relating to climate risks adaptation. }\end{array}$} & Yes & 62 & 34.4 \\
\hline & & No & 118 & 65.6 \\
\hline \multirow{2}{*}{6.} & \multirow{2}{*}{$\begin{array}{l}\text { Potential of community involvement } \\
\text { in climate change discussions }\end{array}$} & Yes, better result & 118 & 65.6 \\
\hline & & Uncertain & 62 & 34.4 \\
\hline
\end{tabular}

Table 5. Suggestions for climate change adaptation measures in densely populated areas.

\begin{tabular}{cccc}
\hline \multirow{2}{*}{ Variable } & Factors & \multicolumn{2}{c}{ Responses } \\
\cline { 3 - 4 } & & Frequency & $\%$ \\
\hline & Alternative electricity & 121 & 67.2 \\
& Awareness programmes & 12 & 6.7 \\
& Community participation & 4 & 2.2 \\
Suggestions for partnership & Urban development & 4 & 2.2 \\
towards climate risk adaptation & Legislation & 4 & 2.2 \\
& Policy & 19 & 10.6 \\
& Power supply & 4 & 2.2 \\
& Regulations & 8 & 4.4 \\
\hline
\end{tabular}

Table 6. Degree of variations in key climate components within the study area.

\begin{tabular}{|c|c|c|c|c|c|c|c|c|c|c|c|}
\hline \multirow{3}{*}{ Variable } & \multirow{3}{*}{ Factors } & \multicolumn{10}{|c|}{ Responses } \\
\hline & & \multicolumn{2}{|c|}{ Very drastic } & \multicolumn{2}{|c|}{ Moderately drastic } & \multicolumn{2}{|c|}{ Average } & \multicolumn{2}{|c|}{ Small change } & \multicolumn{2}{|c|}{ No change } \\
\hline & & Frequency & $\%$ & Frequency & $\%$ & Frequency & $\%$ & Frequency & $\%$ & Frequency & $\%$ \\
\hline & Rainfall & 38 & 29.2 & 36 & 27.7 & 56 & 43.1 & & & & \\
\hline $\begin{array}{l}\text { Degree of } \\
\text { change in }\end{array}$ & Flooding & 63 & 48.5 & 35 & 26.9 & 4 & 3.1 & & & 28 & 21.5 \\
\hline \multirow{2}{*}{$\begin{array}{l}\text { key climate } \\
\text { components }\end{array}$} & Sun intensity & 50 & 38.5 & 66 & 50.8 & 4 & 3.1 & & & 10 & 7.7 \\
\hline & River overflow/Erosion & 14 & 10.8 & 55 & 42.3 & 31 & 23.8 & 18 & 13.8 & 12 & 9.2 \\
\hline
\end{tabular}


Table 7. Degree of risks associated with alternative electricity sources in the study area.

\begin{tabular}{|c|c|c|c|c|c|c|c|c|c|c|c|}
\hline \multirow{3}{*}{ Variable } & \multirow{3}{*}{ Factors } & \multicolumn{10}{|c|}{ Responses } \\
\hline & & \multicolumn{2}{|c|}{ Very risky } & \multicolumn{2}{|c|}{ Moderately risky } & \multicolumn{2}{|c|}{ Small risk } & \multicolumn{2}{|c|}{ No risk } & \multicolumn{2}{|c|}{ Not sure } \\
\hline & & Frequency & $\%$ & Frequency & $\%$ & Frequency & $\%$ & Frequency & $\%$ & Frequency & $\%$ \\
\hline \multirow{4}{*}{$\begin{array}{l}\text { Degree of risk } \\
\text { associated with } \\
\text { alternative } \\
\text { electricity resources }\end{array}$} & Inverter & 14 & 7.8 & 4 & 2.2 & 44 & 24.4 & 78 & 43.3 & 40 & 22.2 \\
\hline & Generator & 134 & 74.4 & 24 & 13.3 & 12 & 6.7 & & & 10 & 5.6 \\
\hline & Lantern & 138 & 76.7 & 28 & 15.6 & & & & & 14 & 7.8 \\
\hline & Candle & 166 & 92.2 & 14 & 7.8 & & 23.8 & & & & \\
\hline
\end{tabular}

Table 8. Current climate risk adaptation measures in the study area.

\begin{tabular}{|c|c|c|c|c|c|c|c|c|c|c|c|}
\hline \multirow{3}{*}{ Variable } & \multirow{3}{*}{ Factors } & \multicolumn{10}{|c|}{ Responses } \\
\hline & & \multicolumn{2}{|c|}{ Very effective } & \multicolumn{2}{|c|}{ Effective } & \multicolumn{2}{|c|}{ Unable to access } & \multicolumn{2}{|c|}{ Little effective } & \multicolumn{2}{|c|}{ Not effective } \\
\hline & & Frequency & $\%$ & Frequency & $\%$ & Frequency & $\%$ & Frequency & $\%$ & Frequency & $\%$ \\
\hline \multirow{4}{*}{$\begin{array}{l}\text { Current } \\
\text { climate risk } \\
\text { adaptation } \\
\text { measures }\end{array}$} & $\begin{array}{l}\text { Avoid using risk } \\
\text { materials }\end{array}$ & 18 & 11.5 & 31 & 19.9 & 4 & 2.6 & 57 & 36.5 & 46 & 29.5 \\
\hline & Relocation & & & 31 & 19.9 & 24 & 15.4 & 26 & 16.7 & 75 & 48.1 \\
\hline & $\begin{array}{c}\text { Alternative } \\
\text { energy resources }\end{array}$ & 54 & 34.6 & 49 & 31.4 & 10 & 6.4 & & & 43 & 27.6 \\
\hline & $\begin{array}{l}\text { Reduction in the use } \\
\text { of high risk materials }\end{array}$ & 50 & 32.1 & 57 & 36.5 & & & 10 & 6.4 & 39 & 25 \\
\hline
\end{tabular}

\section{Results and Discussion}

The results of this study align with the key research questions which focused mostly on evolving an evidence-based strategy for climate risk adaptation in densely populated urban centres. These results also undergird empirical grounding on the level of climate risk awareness within the study area, the reality of climate change and its associated risks, alternative sources of electricity, and their impacts on the climate, and the extent of public participation in climate risk adaptation within Abakpa-Nike, Coal-camp and Obiagu urban centres. First and foremost, the data in Table 1 revealed that $37.2 \%$ of the respondents have lived in the study area for more than 15 years, $12.2 \%$ between 11 and 15 years, and $4.4 \%$ between 6 and 10 years. By simple integration and estimating the measure of central tendency, this gives more than $50 \%$ of the respondents who have lived in the study area for more than ten years. Thus, the length of stay in the study area, inter alia, provides an added advantage and significant confidence to the internal validity of the research data.

'With respect to the reality of climate change, its associated risk, and the level of public awareness within the study area which is a key focal area of the present research, the data in Table 2 revealed a moderate knowledge of this through mainly the changing rainfall pattern which was perceived by $63.3 \%$ of the respondents. For this south-eastern city, variation in the spatial and temporal distribution of rainfall lead to water scarcity in most places and in other places 
excess surface water, which overwhelms urban storm drainage systems, and produces urban pluvial flooding (Daramola \& Ibem, 2010; Adegun et al., 2012). This is crucial as there is research evidence to corroborate this result. Climate change is a striking reality in Enugu, as evidenced in major cities within Nigeria. However, judged by the limited climate change information which often undermines effective climate risk communication, it can be argued that the level of awareness of climate risk and adaptation in Enugu is poor. Ozor \& Cynthia (2010) identified such to be a major barrier to climate risk adaptation among farmers in Enugu. From the relics of climate history, Enugu has not been one of the states in Nigeria with a known experience of flooding, which accounts to why only as little as $38.9 \%$ and $17.4 \%$ perceived a variation in flood pattern and river overflow. Indeed, prior to 2012, when flooding engulfed nearly threequarters of the states of Nigeria, including Enugu, occurrences of flooding were spasmodic, especially as a result of obsolescent drainage systems which no longer convey rain water to streams and rivers, resulting to heavy overland flows which hardly lasted much longer. These manifestations threaten mainly the sustainable development of the Enugu urban, although low agricultural productivity due to the unpredictable weather patterns is also a major footprint of climate change within the city, and this affects food security for the urban dwellers (Odjugo, 2010; Ozor \& Cynthia, 2011).

Besides flooding and heavy rainfall, the perception of increased sun intensity is also crucial to this research as nearly $50 \%$ of the respondents were of the opinion that the intensity of the sun has increased. Many research have shown that Increased land surface temperatures instigate urban heat, which has been shown to have a significant impact on the overall economic wellbeing of the metropolis (Christian \& Izuchukwu, 2009; Enete et al., 2012; Christian \& Ugoyibo, 2013; Ezenwaji et al., 2014). These studies provided empirical evidence to show that the scourge of urban heat due to increasing climate in Enugu is a real problem for the urban areas. In understanding the nature of the changes that have occurred in these key components of climate change, Table 6 shows that the change in the pattern of rainfall is only average (43.1\%), compared to urban heat (50.8\%) and flooding (48.5\%), both of which have been characterised as moderate and drastic changes in their occurrences respectively.

Underpinning the key indicators of climate change in the present context is the source of climate change knowledge, which is also crucial in harnessing resources to formulate policy and strategic plans for adaptation. Data from the research revealed that much of the knowledge of climate change was acquired through the media, especially radio, newspaper, and TV, all of which represent $47.7 \%, 30.3 \%$, and $13.9 \%$ respectively. This revealed the impacts of the media and national orientation towards increasing the local knowledge of climate change within the DCs urban areas. $16.8 \%$ of the respondents acknowledged that public gathering through the church was also a source of climate change knowledge. This is especially inspiring to note given the growing attention of the roles of faith-based organisation in climate change mitigation and adaptation which is 
now a new research paradigm as presented in Schipper (2010), Conway \& Schipper (2011), Mulyasari \& Shaw (2012) and Glaab (2017). With the growing number of churches and other religious gatherings in the study area, such a research would be crucial to undertake.

Electricity supply is a major concern for sustainable development of Enugu city. Besides the ample literature evidence (see Odjugo, 2010 and Ohimain, 2015), the characteristic nature of this situation is shown in the data summarised in Table 3, which indicates a sharp progression from unsteady supply through poor and irregular supply to no supply at all. Although only a negligible proportion (2.2\%) - the outliers-of the respondents acknowledge "steady-state supply" and "no supply" of electricity, the majority (i.e. $27 \%$ and 60\%) respectively agreed on irregular and poor supply. These outliers are perhaps those who reside in heavy government housing areas or places which for some uncertain reasons do not experience black out. As a result of this general lack of electricity supply, many of the urban dwellers have resorted to a number of unconventional alternatives, some of which are also summarised in Table 3 along with their associated risks. The use of a generator was acknowledged by $81.1 \%$ of the respondents, Lanterns (both rechargeable and kerosene/gas powered) by 13.3\%, while candle was acknowledged by $5.6 \%$. The significant implication of these to climate change was also acknowledged given that the risks of these includes fire outbreak (37.8\%), air pollution (22.2\%), noise pollution (25\%). Due to their limited scientific knowledge of climate change, none of the respondents could associate this risk to depletion of the ozone layer. However, $15 \%$ of the respondents acknowledged that the risk of these alternative sources applied to all components related to climate change. In estimating the level of risk associated with each of these alternative sources, Table 7 indicates that $74.4 \%$ adduced that it was very risky to use the generating set as an alternative source of electricity. About $76.7 \%$ of the respondents still agreed that using lantern as an alternative is very risky. However, it was agreed to be even worse (93.2\% of the respondents) to use lantern.

Regarding the level of the public participation in urban development and policy within the study areas, the data summarised in Table 4 indicates that $82.2 \%$ of the respondents agreed that the public is not often considered in decision regarding urban development such as siting markets, schools, medical centers, parks within the vicinity. This is despite the fact that public participation within the areas has a high potential (as agreed by $78.9 \%$ of the respondents). Equally, public participation in climate change adaptation decisions is limited. Only about $34.4 \%$ of the respondents agree to be included in such a programme. The rest of the respondents (65.6\%) denied having any involvement in the climate adaptation decisions. The consequence of this non-involvement of the public is seen in the awareness campaign, which, although should have fostered a greater impact on the mitigation and adaptation efforts within the study areas, has been little undertaken as confirmed by more than $62.2 \%$ of the valid responses. Many cross-disciplinary studies, for examples, Few et al. (2007), Van Aalst et al. (2008) 
and Adger et al. (2013) focused on improving community participation in climate risk adaptation, and within the present research, valid responses from the questionnaire (65.6\%) agree absolutely (100\%) to the high potential of community participation in climate change adaptation within the study areas. The inability of policy makers to involve the public or encourage public participation in siting facilities has arguably resulted in haphazard development in most developing cities in the world, and counterproductive as the majority of the public would have made very high and comprehensive input if they were consulted (Devas \& Grant, 2003; Wilson et al., 2019).

The current climate risk adaptation measures are summarized in Table 5. It can be deduced from the valid responses that the use of alternative sources of electricity, such as renewable sources is being practised in the study area, as more than $65 \%$ of the respondents consent to its effectiveness. $27.6 \%$ of the respondents were of a contrary view, perhaps due to the cost of installing such a system. Thus, based on a cost-benefit analysis, it is important to consider the long-term benefits of renewable energy resources for rural and urban community electrification (Hunt \& Watkiss, 2011; Fankhauser, 2013). Other current methods include avoidance of risky materials for electrification agreed by $31.4 \%$ of the respondents. $36.5 \%$ were of the view that the effects of such a measure are negligible, While the remaining $29.5 \%$ argued that it was not effective at all. Relocation of the community was also being practiced. In this regard, only $19.5 \%$ of the respondents consented to its effectiveness, $16.9 \%$ argue that it is of negligible effect, while $48.1 \%$ were of the view that the measure was counterproductive. The major concern with the relocation of communities due to climate change has been the socio-cultural and economic consideration (de Sherbinin et al., 2011; Jamero et al., 2017; Arnall et al., 2013) and in the present study such a consideration is being opined by the respondents. Finally, reduction in the use of some environmentally-sensitive materials was also mentioned as a current measure to climate change adaptation. Unfortunately, the recycling policy is not in place in the study areas, these non-degradable materials are disposed of randomly. This is a major concern for climate in the DCs and poor urban communities (Nabegu, 2011). However, the present research identified the need to minimise the use of certain materials such as plastic, which can increase the emission of CO if combusted. From the table, 32.5\% of the respondents consent to this measure being effective, $36.5 \%$ argue that its effect was only negligible While $25 \%$ argue that it was not effective at all. Evidently, adaptation to climate change and associated risk in many of these DCs is often undermined by the lack of access to quality data and poor urban development framework, which is compounded by the limited public participation in climate risk adaptation policy formulation and planning process. Moreover, institutional capacities are constrained by avoidable bureaucracies in the delivery of desired urban development goals.

The respondents were given the opportunity to suggest what they felt was more effective way of climate risk adaptation in the study areas. Ranked top 
among the suggestions is alternative energy resources, which is renewable energy, agreed upon by $67.2 \%$ of the respondents. Formulation of more effective climate risk adaptation policies (10.6\%) and improving on the current climate risk awareness within the areas (6.7\%) were also suggested. Other measures were enforcing climate change regulation (4.4\%), improving upon community participation (2.2\%), enhancing the current power supply (2.2\%), urban development (2.2) and climate change legislation (2.2\%).

\section{Conclusion and Recommendations}

This research examined the adaptation measures to climate risk in densely populated urban localities caused by poor electricity supply. The main objectives were to investigate the general perception of climate change, community participation in urban development, and climate risk adaptation measures using $\mathrm{Ab}$ akpa-Nike and Obiagu, both of which are two densely populated localities within Enugu city. The research was undertaken by a survey of 180 participants aged 18 - 55 years, randomly selected in the study area, and administered with a questionnaire to respond to questions regarding the main rationale and key objectives and for the research.

The results of the research indicate that the areas have been largely subject to a poor supply of electricity from the national grid-Enugu Electricity Distribution company (EEDC). This situation has prompted urban dwellers to consider alternative sources, such as candles, lanterns and generators, all of which are major drivers of climate change by the emission of CO (Carbon II Oxide) into the atmosphere. Renewable energy resources are also considered by a few, although the cost of installing soft hardware has been a major limitation. Knowledge of climate change in the study area is satisfactory, given that more than $60 \%$ of the respondents perceived a drastic variation in the pattern of rainfall over the recent past. A substantial number of other respondents also perceived an increase in the rate of flash and pluvial flooding and the intensity of urban heat within the city. These are major indicators of climate change in many cities as recorded within the current literature (Nkwunonwo \& Mafimisebi, 2013).

However, despite this knowledge, there is clear evidence of limited community participation in both urban development and climate risk adaptation measures within the study area. This is despite the high potential of community participation, which is as high as $100 \%$ from the data for valid questionnaire responses that could have on both urban development and climate risk adaptation measures within the areas. Similar to other places within the DCs, climate risk adaptation in Enugu is constrained by competing sustainable urban development objectives, and this is an issue of grave research concern (Adger et al., 2003). This is compounded by the lack of data of reputable quality, along with other technological capacity required to analyse and assess the components of risk (Nzeh \& Eboh, 2011; Nkwunonwo et al., 2016b). Institutional structures and policy instruments that support adaptation measures are poorly developed and 
often marked by extended chains in the delivery of desired goals (Stringer et al., 2009). Adequate urban development framework and planning necessary to ensure a proper redelivery of urban services such as hospitals, schools, recreational facilities, waste management, communication, and social orientation tools are limited (Nzeadibe, 2009; Ali, 2010). Currently, urban policies are formulated solely by government officials without data or with imprecise data and worse still, without seeking opinion of key stakeholders such as the target community (Nzeadibe, 2009; Daramola \& Ibem, 2010; Onodugo et al., 2016). Consequently, the wider population neither sufficiently understands the rationale for the policies nor owns them. The implication is poor understanding of climatic risk issues and inadequate preparation to adapt even when early warnings are issued. This situation makes a participatory involvement model of strategic planning a potential panacea to enhance citizens' adaption to climatic risks. Suggestions for the way forward for climate risk adaptation within the place were in favour of renewable energy resources, robust climate risk policy and legislation, avoidance of high-risk materials for domestic and industrial purposes. The study offers significant reinforcement to the present climate risk adaptation in the area, enables increased public participation in policy formulation, simplifies the present topdown approach in policy making and delivery of urban development goals, and supports achieving the goal of building a society resilient to climate risk. However, a major limitation in the design of the research was the neglect of other anthropogenic activities that contribute to climate change such as industrialization, cooking, and waste disposal. These are however recommended for future studies.

\section{Acknowledgements}

This research has not been supported by any public research funds. However, its motivation came from a previous research which was funded by the UNN-ETF academic staff intervention policy of Nigeria. Hence, the authors acknowledge the government of Nigeria for its research and academic initiatives. The author would like to acknowledge specifically the work of a myriad of authors in the field of climate change, vulnerability, resilience, and adaptation. Finally, the authors appreciate the incisive and valuable input from the handling editor and anonymous reviewers.

\section{Conflicts of Interest}

The authors declare no conflicts of interest regarding the publication of this paper.

\section{References}

Aaker, D. A. (2009). Managing Assets and Skills: The Key to a Sustainable Competitive Advantage. California Management Review, 31, 91-106. https://doi.org/10.2307/41166561

Adegun, O., Balogun, I., \& Adeaga, O. (2012). Precipitation Concentration Changes in Owerri and Enugu. Special Publication of the Nigerian Association of Hydrological 
Sciences, 383-391.

Adger, W. N. (2010). Social Capital, Collective Action, and Adaptation to Climate Change. In M. Voss (Ed.), Der Klimawandel (pp. 327-345). VS Verlag für Sozialwissenschaften. https://doi.org/10.1007/978-3-531-92258-4_19

Adger, W. N., Barnett, J., Brown, K., Marshall, N., \& O’brien, K. (2013). Cultural Dimensions of Climate Change Impacts and Adaptation. Nature Climate Change, 3, 112-117. https://doi.org/10.1038/nclimate1666

Adger, W. N., Huq, S., Brown, K., Conway, D., \& Hulme, M. (2003). Adaptation to Climate Change in the Developing World. Progress in Development Studies, 3, 179-195. https://doi.org/10.1191/1464993403ps060oa

Ali, A. N. (2010). An Assessment of the Quality of Intra-Urban Bus Services in the City of Enugu, Enugu State, Nigeria. Theoretical and Empirical Researches in Urban Management, 6, 74-91.

Amit, R., \& Schoemaker, P. J. H. (2003). Strategic Intents and Organizational Rents. Strategic Management Journal, 14, 33-46. https://doi.org/10.1002/smj.4250140105

Aram, J. D., \& Cowen, S. S. (1990). Strategic Planning for Increased Profit in the Small Business. Long Range Planning, 23, 63-70. https://doi.org/10.1016/0024-6301(90)90103-B

Araos, M., Berrang-Ford, L., Ford, J. D., Austin, S. E., Biesbroek, R., \& Lesnikowski, A. (2016). Climate Change Adaptation Planning in Large Cities: A Systematic Global Assessment. Environmental Science \& Policy, 66, 375-382. https://doi.org/10.1016/j.envsci.2016.06.009

Arnall, A., Thomas, D. S., Twyman, C., \& Liverman, D. (2013). Flooding, Resettlement, and Change in Livelihoods: Evidence from Rural Mozambique. Disasters, 37, 468-488. https://doi.org/10.1111/disa.12003

Arrow, K. J. (2007). Global Climate Change: A Challenge to Policy. The Economists' Voice, 4, 1-5. https://doi.org/10.2202/1553-3832.1270

Bain, J. S. (1968). Industrial Organization. New York: John Wiley.

Barney, J. B. (1991). Firm Resources and Sustained Competitive Advantage. Journal of Management, 17, 99-120. https://doi.org/10.1177/014920639101700108

Barney, J. B. (2002). Gaining and Sustaining Competitive Advantage. Upper Saddle River, NJ: Prentice Hall.

Bazilian, M., Hobbs, B. F., Blyth, W., MacGill, I., \& Howells, M. (2011). Interactions between Energy Security and Climate Change: A Focus on Developing Countries. Energy Policy, 39, 3750-3756. https://doi.org/10.1016/j.enpol.2011.04.003

Bowyer, P., Bender, S., Rechid, D., \& Schaller, M. (2014). Adapting to Climate Change: Methods and Tools for Climate Risk Management (124 p). Germany: Climate Service Center.

Boyd, B. K., \& Reuning-Elliott, E. (1998). A Measurement Model of Strategic Planning. Strategic Management Journal, 19, 181-192. https://doi.org/10.1002/(SICI)1097-0266(199802)19:2<181::AID-SMJ945>3.0.CO;2-Z

Broman, G. I., \& Robèrt, K. H. (2017). A Framework for Strategic Sustainable Development. Journal of Cleaner Production, 140, 17-31.

https://doi.org/10.1016/j.jclepro.2015.10.121

Bryson, J. M. (2011). Strategic Planning for Public and Non-Profit Organizations: A Guide to Strengthening and Sustaining Organizational Achievement (Vol. 1). Hoboken, NJ: John Wiley \& Sons.

Burch, S., Sheppard, S. R., Shaw, A., \& Flanders, D. (2010). Planning for Climate Change 
in a Flood-Prone Community: Municipal Barriers to Policy Action and the Use of Visualizations as Decision-Support Tools. Journal of Flood Risk Management, 3, 126-139. https://doi.org/10.1111/j.1753-318X.2010.01062.x

Christian, E. I., \& Izuchukwu, E. (2009). Analysis of Rainfall Distribution over Enugu during the Little Dry Season (1990-2005). Journal of Geography and Regional Planning, 2, 182-189.

Christian, E. I., \& Ugoyibo, O. V. (2013). Mapping Enugu City's Urban Heat Island. International Journal of Environmental Protection and Policy, 1, 50-58. https://doi.org/10.11648/j.ijepp.20130104.12

Conway, D., \& Mustelin, J. (2014). Strategies for Improving Adaptation Practice in Developing Countries. Nature Climate Change, 4, 339-342.

https://doi.org/10.1038/nclimate2199

Conway, D., \& Schipper, E. L. F. (2011). Adaptation to Climate Change in Africa: Challenges and Opportunities Identified from Ethiopia. Global Environmental Change, 21, 227-237. https://doi.org/10.1016/j.gloenvcha.2010.07.013

Crowley, T. J. (2000). Causes of Climate Change over the Past 1000 Years. Science, 289, 270-277. https://doi.org/10.1126/science.289.5477.270

Daramola, A., \& Ibem, E. O. (2010). Urban Environmental Problems in Nigeria: Implications for Sustainable Development. Journal of Sustainable Development in Africa, 12, 124-145.

de Sherbinin, A., Castro, M., Gemenne, F., Cernea, M. M., Adamo, S., Fearnside, P. M. et al. (2011). Preparing for Resettlement Associated with Climate Change. Science, 334, 456-457. https://doi.org/10.1126/science.1208821

Devas, N., \& Grant, U. (2003). Local Government Decision-Making-Citizen Participation and Local Accountability: Some Evidence from Kenya and Uganda. Public Administration and Development, 23, 307-316. https://doi.org/10.1002/pad.281

Enete, I. C., Alabi, M. O., \& Chukwudelunzu, V. U. (2012). Tree Canopy Cover Variation Effects on Urban Heat Island in Enugu City, Nigeria. Journal of Developing Country Studies, 2, 12-18.

Ezenwaji, E. E., Anyadike, R. N., \& Igu, N. I. (2014). Optimal Allocation of Public Water Supply to the Urban Sectors of Enugu, Nigeria: A Linear Programming Approach. Applied Water Science, 4, 73-78. https://doi.org/10.1007/s13201-013-0131-0

Fankhauser, S. (2013). Valuing Climate Change: The Economics of the Greenhouse. London: Routledge. https://doi.org/10.4324/9781315070582

Few, R., Brown, K., \& Tompkins, E. L. (2007). Public Participation and Climate Change Adaptation: Avoiding the Illusion of Inclusion. Climate Policy, 7, 46-59. https://doi.org/10.1080/14693062.2007.9685637

Gillard, R., Gouldson, A., Paavola, J., \& Van Alstine, J. (2016). Transformational Responses to Climate Change: Beyond a Systems Perspective of Social Change in Mitigation and Adaptation. WIREs Climate Change, 7, 251-265.

https://doi.org/10.1002/wcc.384

Glaab, K. (2017). A Climate for Justice? Faith-Based Advocacy on Climate Change at the United Nations. Globalizations, 14, 1110-1124.

https://doi.org/10.1080/14747731.2017.1308060

Grant, R. M. (1991). The Resource-Based View of Competitive Advantage: Implication for Strategy Formulation. California Management Journal, 33, 114-135. https://doi.org/10.2307/41166664

Grant, R. M. (2003). Strategic Planning in a Turbulent Environment: Evidence from the 
Oil Majors. Strategic Management Journal, 24, 491-517.

https://doi.org/10.1002/smj.314

Hallegatte, S. (2009). Strategies to Adapt to an Uncertain Climate Change. Global Environmental Change, 19, 240-247. https://doi.org/10.1016/i.gloenvcha.2008.12.003

Henstra, D. (2012). Toward the Climate-Resilient City: Extreme Weather and Urban Climate Adaptation Policies in Two Canadian Provinces. Journal of Comparative Policy Analysis: Research and Practice, 14, 175-194. https://doi.org/10.1080/13876988.2012.665215

Hillier, F. S., \& Price, C. C. (2004). International Series in Operations Research \& Management Science. Palgrave Macmillian, 7, 1-93.

Hinkel, J., Aerts, J. C., Brown, S., Jiménez, J. A., Lincke, D., Nicholls, R. J., Scussolini, P., Sacchez-Arcilla, A., Vafeidis, A., \& Addo, K. A. (2018). The Ability of Societies to Adapt to Twenty-First-Century Sea-Level Rise. Nature Climate Change, 8, 570-578. https://doi.org/10.1038/s41558-018-0176-Z

Hirabayashi, Y., Mahendran, R., Koirala, S., Konoshima, L., Yamazaki, D., Watanabe, S., Kim, H., \& Kanae, S. (2013). Global Flood Risk under Climate Change. Nature Climate Change, 3, 816-821. https://doi.org/10.1038/nclimate1911

Hoffmann, A. A., \& Sgrò, C. M. (2011). Climate Change and Evolutionary Adaptation. Nature, 470, 479-485. https://doi.org/10.1038/nature09670

Hunt, A., \& Watkiss, P. (2011). Climate Change Impacts and Adaptation in Cities: A Review of the Literature. Climatic Change, 104, 13-49.

https://doi.org/10.1007/s10584-010-9975-6

Intergovernmental Panel on Climate Change, IPCC (2014). Climate Change 2014-Impacts, Adaptation and Vulnerability: Regional Aspects. Cambridge: Cambridge University Press.

International Energy Agency, IEA (2016). World Energy Outlook 2016 Executive Summary. Paris, France: International Energy Agency. https://doi.org/10.1787/weo-2016-en

Jakob, M., Chen, C., Fuss, S., Marxen, A., \& Edenhofer, O. (2015). Development Incentives for Fossil Fuel Subsidy Reform. Nature Climate Change, 5, 709-712. https://doi.org/10.1038/nclimate2679

Jamero, M. L., Onuki, M., Esteban, M., Billones-Sensano, X. K., Tan, N., Nellas, A. et al. (2017). Small-Island Communities in the Philippines Prefer Local Measures to Relocation in Response to Sea-Level Rise. Nature Climate Change, 7, 581-586. https://doi.org/10.1038/nclimate3344

Jones, H. P., Hole, D. G., \& Zavaleta, E. S. (2012). Harnessing Nature to Help People Adapt to Climate Change. Nature Climate Change, 2, 504-509. https://doi.org/10.1038/nclimate1463

Kates, R. W., Travis, W. R., \& Wilbanks, T. J. (2012). Transformational Adaptation When Incremental Adaptations to Climate Change Are Insufficient. Proceedings of the National Academy of Sciences of the United States of America, 109, 7156-7161. https://doi.org/10.1073/pnas.1115521109

Kaufmann, R. K., Kauppi, H., Mann, M. L., \& Stock, J. H. (2011). Reconciling Anthropogenic Climate Change with Observed Temperature 1998-2008. Proceedings of the National Academy of Sciences of the United States of America, 108, 11790-11793. https://doi.org/10.1073/pnas.1102467108

Kraaijenbrink, J., Spender, J. C., \& Groen, A. J. (2010). The Resource-Based View: A Review and Assessment of Its Critiques. Journal of Management, 36, 349-372. https://doi.org/10.1177/0149206309350775

Kunaifi \& Reinders, A. (2018). Perceived and Reported Reliability of the Electricity Supply at Three Urban Locations in Indonesia. Energies, 11, 140-167. 
https://doi.org/10.3390/en11010140

Lenderink, G., \& Van Meijgaard, E. (2008). Increase in Hourly Precipitation Extremes beyond Expectations from Temperature Changes. Nature Geoscience, 1, 511-514. https://doi.org/10.1038/ngeo262

Lutz, W., \& Muttarak, R. (2017). Forecasting Societies' Adaptive Capacities through a Demographic Metabolism Model. Nature Climate Change, 7, 177-184. https://doi.org/10.1038/nclimate3222

Mahoney, J. T., \& Pandian, J. R. (1992). The Resource-Based View within the Conversation of Strategic Management. Strategic Management Journal, 13, 363-380. https://doi.org/10.1002/smj.4250130505

Marfai, M. A., Sekaranom, A. B., \& Ward, P. (2015). Community Responses and Adaptation Strategies toward Flood Hazard in Jakarta, Indonesia. Natural Hazards, 75, $1127-$ 1144. https://doi.org/10.1007/s11069-014-1365-3

McLeman, R. (2010). Impacts of Population Change on Vulnerability and the Capacity to Adapt to Climate Change and Variability: A Typology Based on Lessons from "a Hard Country". Population and Environment, 31, 286-316. https://doi.org/10.1007/s11111-009-0087-Z

McMichael, A. J., Woodruff, R. E., \& Hales, S. (2006). Climate Change and Human Health: Present and Future Risks. The Lancet, 367, 859-869. https://doi.org/10.1016/S0140-6736(06)68079-3

Measham, T. G., Preston, B. L., Smith, T. F., Brooke, C., Gorddard, R., Withycombe, G., \& Morrison, C. (2011). Adapting to Climate Change through Local Municipal Planning: Barriers and Challenges. Mitigation and Adaptation Strategies for Global Change, 16, 889-909. https://doi.org/10.1007/s11027-011-9301-2

Miller, C. C., \& Cardinal, L. B. (1994). Strategic Planning and Firm Performance: A Synthesis of More than Two Decades of Research. Academy of Management Journal, 37, 1649-1665.

Missimer, M., Robèrt, K. H., \& Broman, G. (2017). A Strategic Approach to Social Sustainability-Part 1: Exploring the Social System. Journal of Cleaner Production, 140, 32-41. https://doi.org/10.1016/j.jclepro.2016.03.170

Moss, R. H., Edmonds, J. A., Hibbard, K. A., Manning, M. R., Rose, S. K., Van Vuuren, D. P., Carter, T. R., Emori, S., Kainuma, M., Kram, T., Meehl, G. A., John, F. B., Mitchell, J. F. B., Mote, P. W., \& Salathe, E. P. (2010). Future Climate in the Pacific Northwest. Climatic Change, 102, 29-50. https://doi.org/10.1007/s10584-010-9848-Z

Mukheibir, P., \& Ziervogel, G. (2007). Developing a Municipal Adaptation Plan (MAP) for Climate Change: The City of Cape Town. Environment and Urbanization, 19, 143158. https://doi.org/10.1177/0956247807076912

Mulyasari, F., \& Shaw, R. (2012). Chapter 8. Civil Society Organization and Disaster Risk Reduction in Indonesia: Role of Women, Youth, and Faith-Based Groups. In R. Shaw (Ed.), Community-Based Disaster Risk Reduction (pp. 131-150). Bingley: Emerald Group Publishing Limited. https://doi.org/10.1108/S2040-7262(2012)0000010014

Nabegu, A. B. (2011). Solid Waste and Its Implications for Climate Change in Nigeria. Journal of Human Ecology, 34, 67-73. https://doi.org/10.1080/09709274.2011.11906370

Nkwunonwo, U. C. (2015). Digital Mapping of Soil Chemical Properties for Erosion Hazard Management in Bayelsa State, Nigeria. Chemical Science Review and Letters, 4, 209-217.

Nkwunonwo, U. C., \& Mafimisebi, O. P. (2013). Responding to the Challenges of Global Climate Change in Nigeria through GIS Mapping of Carbon IV Oxide Gas Emission. International Journal of Science and Engineering Research, 4, 765-774. 
Nkwunonwo, U. C., Chiemelu, N. E., \& Nkwunonwo, U. A. (2016b). Exploring the Inadequacy of Pertinent Capacities for Urban Flood Risk Management in the Developing Countries. Journal of Social Sciences, 12, 136-151.

https://doi.org/10.3844/jssp.2016.136.151

Nkwunonwo, U. C., Whitworth, M., \& Baily, B. (2016a). Review Article: A Review and Critical Analysis of the Efforts towards Urban Flood Risk Management in the Lagos Region of Nigeria. Natural Hazards and Earth System Sciences, 16, 349-369. https://doi.org/10.5194/nhess-16-349-2016

Nzeadibe, T. C. (2009). Solid Waste Reforms and Informal Recycling in Enugu Urban Area, Nigeria. Habitat International, 33, 93-99. https://doi.org/10.1016/j.habitatint.2008.05.006

Nzeh, E. C., \& Eboh, O. R. (2011). Technological Challenges of Climate Change Adaptation in Nigeria: Insights from Enugu State (pp. 1-38). African Technology Policy Studies Network Working Paper Series 52.

Odjugo, P. A. O. (2010). General Overview of Climate Change Impacts in Nigeria. Journal of Human Ecology, 29, 47-55. https://doi.org/10.1080/09709274.2010.11906248

Ohimain, E. I. (2015). Diversification of Nigerian Electricity Generation Sources. Energy Sources, Part B: Economics, Planning, and Policy, 10, 298-305. https://doi.org/10.1080/15567249.2010.551249

Onodugo, V. A., Ezeadichie, N. H., Onwuneme, C. A., \& Anosike, A. E. (2016). The Dilemma of Managing the Challenges of Street Vending in Public Spaces: The Case of Enugu City, Nigeria. Cities, 59, 95-101. https://doi.org/10.1016/i.cities.2016.06.001

Ozor, N., \& Cynthia, N. (2010). Difficulties in Adaptation to Climate Change by Farmers in Enugu State, Nigeria. Journal of Agricultural Extension, 14, 106-122. https://doi.org/10.4314/jae.v14i2.64127

Ozor, N., \& Cynthia, N. (2011). The Role of Extension in Agricultural Adaptation to Climate Change in Enugu State, Nigeria. Journal of Agricultural Extension and Rural Development, 3, 42-50.

Penrose, E. T. (1959). The Theory of Growth of the Firm? London: Basil Blackwell.

Peteraf, M. A., \& Barney, J. B. (2003). Unravelling the Resource-Based Tangle. Managerial and Decision Economics, 24, 309-323. https://doi.org/10.1002/mde.1126

Pineau, P. O. (2008). Electricity Sector Integration in West Africa. Energy Policy, 36, 210-223. https://doi.org/10.1016/j.enpol.2007.09.002

Poister, T. H. (2010). The Future of Strategic Planning in the Public Sector: Linking Strategic Management and Performance. Public Administration Review, 70, s246-s254. https://doi.org/10.1111/j.1540-6210.2010.02284.x

Poister, T. H., \& Streib, G. (2005). Elements of Strategic Planning and Management in Municipal Government: Status after Two Decades. Public Administration Review, 65, 45-56. https://doi.org/10.1111/j.1540-6210.2005.00429.x

Porter, M. E. (1996). What Is Strategy? Harvard Business Review, 2, 61-78.

Porter, M. E. (2001). Toward a Dynamic Theory of Strategy. Strategic Management Journal, 12, 95-117. https://doi.org/10.1002/smj.4250121008

Reenberg, A., Birch-Thomsen, T., Mertz, O., Fog, B., \& Christiansen, S. (2008). Adaptation of Human Coping Strategies in a Small Island Society in the SW Pacific-50 Years of Change in the Coupled Human-Environment System on Bellona, Solomon Islands. Human Ecology, 36, 807-819. https://doi.org/10.1007/s10745-008-9199-9

Runhaar, H., Mees, H., Wardekker, A., van der Sluijs, J., \& Driessen, P. P. (2012). Adaptation to Climate Change-Related Risks in Dutch Urban Areas: Stimuli and Barriers. Re- 
gional Environmental Change, 12, 777-790. https://doi.org/10.1007/s10113-012-0292-7

Schipper, E. L. F. (2010). Religion as an Integral Part of Determining and Reducing Climate Change and Disaster Risk: An Agenda for Research. In M. Voss (Ed.), Der Klimawandel (pp. 377-393). VS Verlag für Sozialwissenschaften.

https://doi.org/10.1007/978-3-531-92258-4 22

Schipper, L., \& Pelling, M. (2006). Disaster Risk, Climate Change and International Development: Scope for, and Challenges to, Integration. Disasters, 30, 19-38. https://doi.org/10.1111/j.1467-9523.2006.00304.x

Shafiullah, G. M., Oo, A. M., Ali, A. S., \& Wolfs, P. (2013). Smart Grid for a Sustainable Future. Smart Grid and Renewable Energy, 4, 23-34.

https://doi.org/10.4236/sgre.2013.41004

Smit, B., \& Pilifosova, O. (2003). Adaptation to Climate Change in the Context of Sustainable Development and Equity. Sustainable Development, 8, 1-9.

Smit, B., \& Wandel, J. (2006). Adaptation, Adaptive Capacity and Vulnerability. Global Environmental Change, 16, 282-292. https://doi.org/10.1016/j.gloenvcha.2006.03.008

Stringer, L. C., Dyer, J. C., Reed, M. S., Dougill, A. J., Twyman, C., \& Mkwambisi, D. (2009). Adaptations to Climate Change, Drought and Desertification: Local Insights to Enhance Policy in Southern Africa. Environmental Science \& Policy, 12, 748-765.

https://doi.org/10.1016/j.envsci.2009.04.002

Tàbara, J. D., Jäger, J., Mangalagiu, D., \& Grasso, M. (2019). Defining Transformative Climate Science to Address High-End Climate Change. Regional Environmental Change, 19, 807-818. https://doi.org/10.1007/s10113-018-1288-8

Tanskanen, J. H. (2000). Strategic Planning of Municipal Solid Waste Management. Resources, Conservation and Recycling, 30, 111-133. https://doi.org/10.1016/S0921-3449(00)00056-2

Tohidi, H., Jafari, A., \& Afshar, A. A. (2010). Strategic Planning in Iranian Educational Organizations. Procedia-Social and Behavioural Sciences, 2, 3904-3908. https://doi.org/10.1016/j.sbspro.2010.03.613

Van Aalst, M. K., Cannon, T., \& Burton, I. (2008). Community Level Adaptation to Climate Change: The Potential Role of Participatory Community Risk Assessment. Global Environmental Change, 18, 165-179. https://doi.org/10.1016/j.gloenvcha.2007.06.002

Vedeld, T., Coly, A., Ndour, N. M., \& Hellevik, S. (2016). Climate Adaptation at What Scale? Multi-Level Governance, Resilience, and Coproduction in Saint Louis, Senegal. Natural Hazards, 82, 173-199. https://doi.org/10.1007/s11069-015-1875-7

Wernerfelt, B. (1984). A Resource-Based View of the Firm. Strategic Management Journal, 5, 171-180. https://doi.org/10.1002/smj.4250050207

Wilson, A., Tewdwr-Jones, M., \& Comber, R. (2019). Urban Planning, Public Participation and Digital Technology: App Development as a Method of Generating Citizen Involvement in Local Planning Processes. Environment and Planning B: Urban Analytics and City Science, 46, 286-302. https://doi.org/10.1177/2399808317712515 